\title{
Diet, lifestyle factors and hypercholesterolemia in elderly men and women from Cyprus
}

\author{
Evangelos Polychronopoulos*, Demosthenes B Panagiotakos, Anna Polystipioti
}

It is clarified that the food frequency questionnaire (FFQ) used in the article published in Lipids in Health and Disease [1], as well as in the whole MEDIS study, was a short, semi-quantitative FFQ with 15 questions regarding the basic food groups consumed, as well as with some additional questions regarding beverages' drinking and other nutritional habits [2-4]. The reference Katsouyanni et al., [5] was cited in order to support that in epidemiologic research is common procedure measuring nutritional habits as an average per week during the preceding year (even in the elderly), and was not referring to the FFQ used.

Received: 1 June 2010 Accepted: 24 September 2010

Published: 24 September 2010

\section{References}

1. Polychronopoulos E, Panagiotakos D, Polystipioti A: Diet, lifestyle factors and hypercholesterolemia in elderly men and women from Cyprus. Lipids Health Dis 2005, 4:17.

2. Polystipioti A: Nutritional habits in elderly men and women from Cyprus. MSC Thesis Harokopio University, Athens 2005.

3. Chambou A: Nutritional habits of special population groups (and elderly) in Cyprus. MSC Thesis Harokopio University, Athens 2008.

4. Tyrovolas S, Pounis G, Bountziouka V, Polychronopoulos E, Panagiotakos D: Repeatability and validation of a short, semi-quantitative food frequency questionnaire designed for older adults living in Mediterranean areas: the MEDISFFQ. J Nutr Elder 2010, 29(3):311-24.

5. Katsouyanni K, Rimm EB, Gnardellis C, Trichopoulos D, Polychronopoulos E, Trichopoulou A: Reproducibility and relative validity of an extensive semiquantitative food frequency questionnaire using dietary records and biochemical markers among Greek schoolteachers. Int J Epidemiol 1997, 26:S118-S127.

Submit your next manuscript to BioMed Central and take full advantage of:

- Convenient online submission

- Thorough peer review

- No space constraints or color figure charges

- Immediate publication on acceptance

- Inclusion in PubMed, CAS, Scopus and Google Scholar

- Research which is freely available for redistribution

Submit your manuscript at www biomedcentral.com/submit

\footnotetext{
* Correspondence: epolychronopoulos@yahoo.com

Department of Dietetics - Nutrition, Harokopio University, Athens, Greece
} 